\title{
An effective combination of codon optimization, gene dosage, and process optimization for high-level production of fibrinolytic enzyme in Komagataella phaffii (Pichia pastoris)
}

\author{
Zhiqun Che ${ }^{1}$, Xiaoyan $\mathrm{CaO}^{2}$, Guiguang Chen ${ }^{1}$ and Zhiqun Liang ${ }^{1 *}$
}

\begin{abstract}
Background: As a main drug for diseased thrombus, some clinically used thrombolytic agents have various disadvantages, safer novel thrombolytic agents are of great demand. This study aimed to achieve high and efficient production of a fibrinolytic enzyme with superior enzymatic properties, by a combination strategy of codon optimization, gene dosage and process optimization in Komagataella phaffii (K. phaffii).

Results: After codon optimization, the fibase from a marine Bacillus subtilis was expressed and secreted in K. phaffii GS115. Recombinant strains harboring different copies of the fib gene (fib-nc) were successfully obtained via Geneticin $(0.25-4 \mathrm{mg} / \mathrm{ml})$ screening on minimal dextrose selection plates and assessment via real-time quantitative PCR. The respective levels of fibase produced by strains expressing fib-5.4c, fib-6c, fib-8c, fib-9c, and fib-12c were $4428,5781,7323,7930$, and $2472 \mathrm{U} / \mathrm{ml}$. Levels increased as the copy number increased from 4 to 9 , but decreased dramatically at copy number 12. After high cell density fermentation optimization, the highest fibase activity of the strain expressing fib-9c was $7930 \mathrm{U} / \mathrm{ml}$ in a shake flask and increased to 12,690 U/ml after 3 days of continuous culture in a 5-L fermenter, which is one of the highest levels of production reported. The recombinant fibase was maximally active at $\mathrm{pH} 9.0$ and $45^{\circ} \mathrm{C}$, and was remarkably stable at pH levels ranging from 5 to 10 and temperatures up to $50^{\circ} \mathrm{C}$. As a metal-dependent serine protease, fibase did not cause hemolysis in vitro and preferentially degraded fibrin directly.
\end{abstract}

Conclusions: The combination of codon optimization, gene dosage, and process optimization described herein could be used for the expression of other therapeutic proteins difficult to express. The characteristics of the recombinant fibase suggest that it has potential applications for thrombosis prevention and therapy.

Keywords: Fibrinolytic enzyme, Recombinant engineered strain, Real-time quantification PCR, Fermentation optimization, Characteristics

\footnotetext{
* Correspondence: zqliang@gxu.edu.cn; happyzqliang@163.com

${ }^{1}$ State Key Laboratory for Conservation and Utilization of Subtropical Agro-bioresources, Guangxi Microorganism and Enyme Research Center of Engineering Technology, College of Life Science and Technology, Guangxi University, Nanning 530004, China

Full list of author information is available at the end of the article
}

(c) The Author(s). 2020 Open Access This article is licensed under a Creative Commons Attribution 4.0 International License, which permits use, sharing, adaptation, distribution and reproduction in any medium or format, as long as you give appropriate credit to the original author(s) and the source, provide a link to the Creative Commons licence, and indicate if changes were made. The images or other third party material in this article are included in the article's Creative Commons licence, unless indicated otherwise in a credit line to the material. If material is not included in the article's Creative Commons licence and your intended use is not permitted by statutory regulation or exceeds the permitted use, you will need to obtain permission directly from the copyright holder. To view a copy of this licence, visit http://creativecommons.org/licenses/by/4.0/ The Creative Commons Public Domain Dedication waiver (http://creativecommons.org/publicdomain/zero/1.0/) applies to the data made available in this article, unless otherwise stated in a credit line to the data. 


\section{Background}

In recent years increasing numbers of cardiovascular diseases caused by thrombosis have begun to contribute to impairment of human health, and they are the main reason for morbidity and mortality worldwide [1]. As the main medical drug for diseased thrombus, thrombolytic agents such as urokinase, streptokinase, and tissue-type plasminogen activator have been widely used in clinical therapy. There have always been associated disadvantages however, including high cost, short half-lives, low fibrin specificity, bleeding complications, and allergic responses [2]. There is therefore a demand for safer novel thrombolytic agents. Many fibrinolytic enzymes (fibases) from animals such as snakes [3], earthworms [4, 5], plants [6], the fungus Cordyceps militaris [7] and microbes [8,9] have been discovered and studied extensively. However, there are few reports on fibase produced by marine microorganisms.

Microbial fibases are of great interest to researchers due to their potential for use in thrombolytic therapy, which would be of high yield, low cost, and amenable to industrial scale-up. Over-expression of foreign genes in Escherichia coli (E. coli) commonly leads to the formation of inclusion bodies, resulting in inactive proteins. As an expression system, Bacillus subtilis (B. subtilis) has significant advantages over $E$. coli in that proteins can be readily secreted [10]. But B. subtilis also exhibits high protease expression leading to degradation of target proteins [11], and this high protease expression increases the downstream purification difficulty of target protein. To date two main aspects of protein expression in wild B. subtilis have been investigated. One is the generation of a $B$. subtilis strain rendered deficient in protease expression via gene knock-out [12, 13]. The other is optimization of fermentation processes with respect to high protein expression. The use of yeasts is conducive to facile genetic manipulation and ease of fermentation of the microorganism, which can result in high yields of proteins in a solution that does not contain pyrogens, pathogens, or viral inclusions [14]. Their rapid growth, microbiological safety, and amenability to high-density fermentation in simple media render them particularly suited to large-scale industrial production of foreign proteins, where secretory expression is important for simplifying the downstream protein purification process [15]. In recent years, as one of the most important industrial organisms for heterologous protein production, Komagataella phaffii (K. phaffii) has been used widely for the production of a broad range of recombinant drug products, including antibody fragments [16], growth factors [17], interferon [18], interleukin [19], insulin precursors [20], and staphylococcal kinase [21] etc.
Despite its high protein productivity, further optimization of $K$. phaffii expression is imperative due to strain-specific and product-specific challenges such as promoter strength, methanol utilization type, and oxygen demand. To this end, strategies including genetic and process engineering have been employed in this study. Optimizations of codon use and gene dosage have been proved useful for enhancing protein expression levels. Codon optimization includes the adjustment of codon usage bias and GC content, repeat sequence removal, and undesired sequence motif modification. All these factors could render its mRNA secondary structures more stable, increase the translation efficiency and prolong the half-life of mRNA, and finally result in an increase of protein synthesis [22]. Gene dosage (i.e., the RNA abundance at the transcriptional level) is a major limiting factor for high and efficient expression of the targeted gene. Increasing the gene dosage usually has substantial effects on the improvement of protein expression levels $[23,24]$, and multiple copies of the foreign gene can be inserted at the same site in yeast genomes. Recombinant yeast strains with high expression profiles can be generated by optimizing the number of foreign gene copies inserted. Large-scale production of proteins via high cell density fermentation relies on the optimization of process parameters including methanol feed rate, induction temperature, and specific growth rate [22].

Currently recombinant $K$. phaffii strains with high copy numbers can only be obtained by increasing gene concatemers, so alternative methods for generating multicopy strains rapidly and reliably are highly desirable [25]. Additionally, in order to study the effects of different promoters on protein expression levels, it is necessary to accurately and quantitatively analyze the copy number of foreign genes inserted into the recombinant yeast. In the process of strain propagation, reduced copy number can indicate plasmid loss. Real-time quantification PCR (qPCR) has been used to detect the copy numbers of many foreign genes including transglutaminase [25], human interleukin-3 [26], and lipase [27] in recombinant yeasts, but to date it has not been used in fib gene copy number estimation.

In the current study, after codon optimization, the fibase from a marine B. subtilis D21 was expressed and secreted in $K$. phaffii GS115. Multicopy integrants were obtained via screening and qPCR method to enhance the expression of fibase. Shake flask production series were conducted to optimize cultivation parameters such as medium composition, incubation time, temperature, methanol concentration, and coculture with methanol and sorbitol. After high cell 
density fermentation optimization, the highest fibase activity of the strain expressing fib-9c was $7930 \mathrm{U} / \mathrm{ml}$ in a shake flask and increased to $12,690 \mathrm{U} / \mathrm{ml}$ after 3 days of continuous culture in a 5 - $\mathrm{L}$ fermenter, which is one of the highest levels of production reported. Then fibase was purified using one-step Ni-NTA and its biological characteristics was evaluated.

\section{Methods}

\section{Strains}

The strains and plasmids used are shown in Table 1 . E. coli was cultivated in Luria-Bertani medium at $37^{\circ} \mathrm{C}$, and $K$. phaffii was cultured in buffered glycerol-complex medium (BMGY, $1 \%$ yeast extract, $2 \%$ peptone, $100 \mathrm{mM}$ potassium phosphate buffer, $4 \times$ $10^{-5} \%$ biotin, $1.34 \%$ Yeast Nitrogen Base, $1 \%$ glycerol, $\mathrm{pH}$ 6.0) for growth, buffered methanol-complex medium (BMMY, $1 \%$ yeast extract, $2 \%$ peptone, 100 $\mathrm{mM}$ potassium phosphate buffer, $4 \times 10^{-5} \%$ biotin, 1.34\% Yeast Nitrogen Base, 0.5\% methanol, pH 6.0) for fibase induction, or yeast extract peptone dextrose (YPD) free of glucose (1\% yeast extract and 2\% peptone) for growth and induction.

\section{Construction, transformation, and screening for recombinant $K$. phaffii}

The fib gene (GenBank: KM519994.1) used in this study was derived from a marine B. subtilis D21 screened previously. For high production, 168 codons in total (approximately 61.1\%) were replaced with the $K$. phaffii-preferred codons (Fig. S1). The codon adaptation index was increased from 0.64 of initial sequence to 0.96 of optimized sequence (a codon adaptation index of 0.8-1.0 is regarded as good for high expression). The optimized fib fragment was digested by EcoRI/ notI and then cloned into the simultaneously digested
pPIC9K vector, together with the a-factor signal peptide under control of the AOX1 promoter. The recombinant plasmid pPIC9K-fib was introduced into competent $E$. coli $\mathrm{DH} 5 \alpha$ by chemical transformation, positive clones were selected by ampicillin (Amp, $100 \mu \mathrm{g} / \mathrm{ml}$ ) resistance, colony PCR and sequencing. The recombinant vector pPIC9K-fib was linearized with $S a c$ I and transformed into competent K. phaffii GS115 cells by electroporation, using the set program with a voltage of $1500 \mathrm{~V}, 25 \mu \mathrm{F}$ capacitance, and $200 \Omega$ resistance. The construction of recombinant pPIC9K-fib is depicted in Fig. 1a, and the process of integration into the genome is depicted in Fig. 1b. The single copy or high copy recombinant K. phaffii GS115/pPIK9K-fib were selected using minimal dextrose selection plates containing different concentrations of Geneticin (G418, 0.25 $\mathrm{mg} / \mathrm{ml}$ of 1 copy, $0.5 \mathrm{mg} / \mathrm{ml}$ of $1-2$ copy, $4 \mathrm{mg} / \mathrm{ml}$ of $7-12$ copy), colony PCR and sequencing, which were inoculated into glucose-free YPD or BMGY at $30{ }^{\circ} \mathrm{C} 200 \mathrm{r} / \mathrm{min}$ for 24 $\mathrm{h}$, then transferred to BMMY for induce expression.

\section{Analysis of fib copy number by real-time quantification PCR}

Five positive clones with different fibase activities were selected for analysis of fib copy numbers, which were estimated via qPCR in the $K$. phaffii genome. The primers and probes used for plasmid construction and qPCR are as shown in Table 2. There is only a single copy of the housekeeper gene TDH1 in the $K$. phaffii genome [28], so the TDH1 copy number can be used to represent the initial copy number of the genome in the template. After the recombinant plasmid Topo-fib and pMD19T-TDH1 were respectively linearized with $\mathrm{Xba \textrm {I }}$ and $\mathrm{BamHI}$ as standards, the absolute copy number of the target gene and reference gene were calculated using Eq. 1 below. The standard curve was constructed using real-time

Table 1 The strains and plasmids used in the current study

\begin{tabular}{|c|c|c|}
\hline & Characteristics & Source \\
\hline \multicolumn{3}{|l|}{ Strains } \\
\hline $\begin{array}{l}\text { B. subtilis } \\
\text { D21 }\end{array}$ & Wild-type strain with fibrinolytic activity & Lab stock \\
\hline $\begin{array}{l}\text { K. phaffii } \\
\text { GS115 }\end{array}$ & His4, host strain, methylotrophic & Lab stock \\
\hline \multicolumn{3}{|l|}{ Plasmids } \\
\hline Topo-fib & Topo harboring an internal 825-bp fib gene fragment & $\begin{array}{l}\text { Current } \\
\text { study }\end{array}$ \\
\hline $\begin{array}{l}\text { pMD19T- } \\
\text { TDH1 }\end{array}$ & pMD19T harboring an internal 1002-bp fib gene fragment & $\begin{array}{l}\text { Current } \\
\text { study }\end{array}$ \\
\hline PPIC9K & $\begin{array}{l}\text { E. coli and K. phaffii shuttle vector; Ampr, G418 containing AOX1 promoter for tightly regulated, methanol-induced ex- } \\
\text { pression of the gene }\end{array}$ & Invitrogen \\
\hline pPIC9K-fib & pPIC9K derivative harboring an internal 825 -bp fib gene fragment & $\begin{array}{l}\text { Current } \\
\text { study }\end{array}$ \\
\hline
\end{tabular}




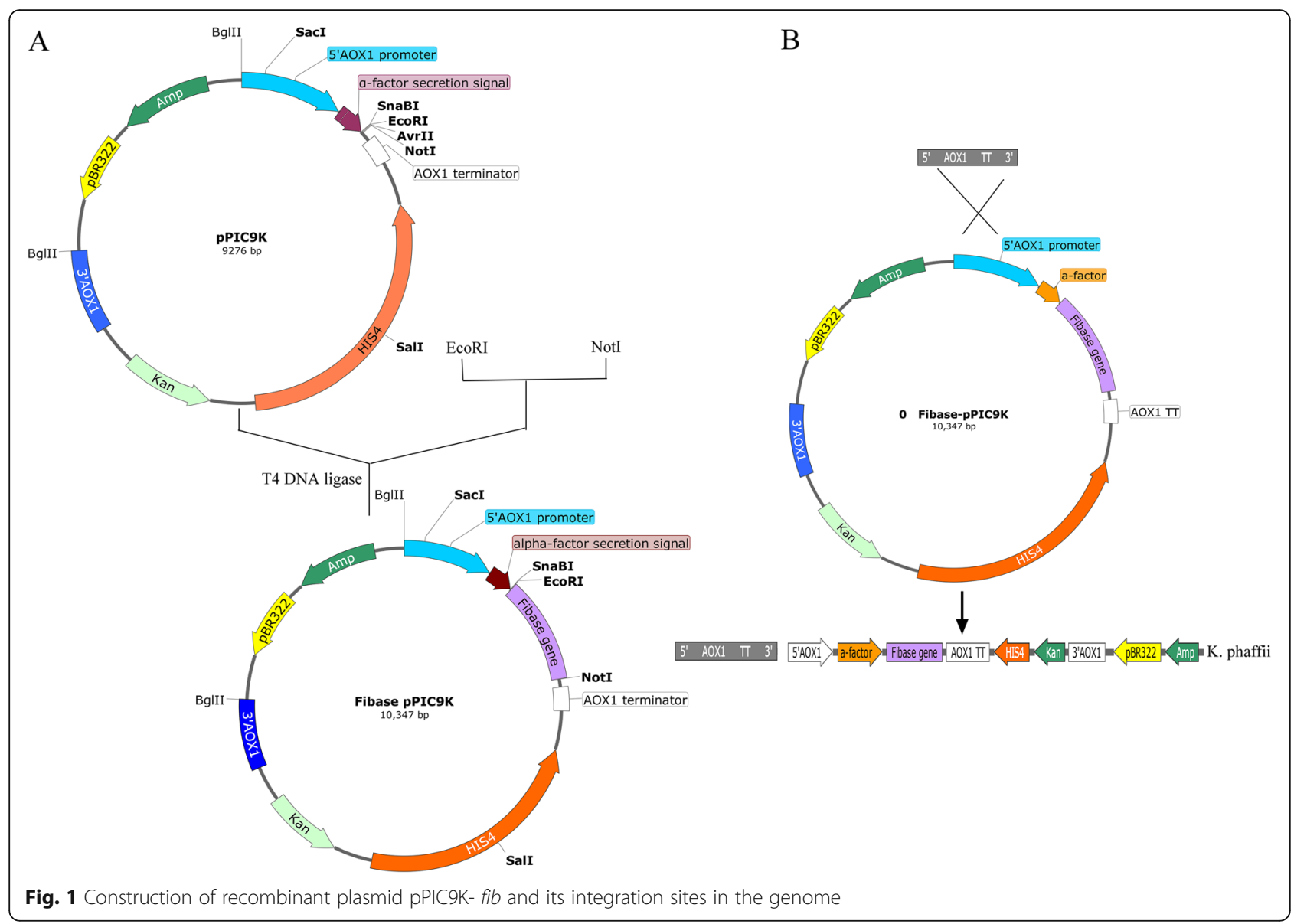

fluorescence quantitative $\mathrm{Ct}$ values and the logarithm of the copy number of the standard (copies/ $\mu \mathrm{l}$ ) after gradient dilution. Using genomes with the highest fibase activity and the aforementioned other four positive clones as sample templates, the absolute copy numbers of the target and reference genes were calculated from $\mathrm{Ct}$ according to the standard curve, then the copy number of the target gene was calculated using Eq. 2 below.

$$
\begin{aligned}
& \text { Copy number } \\
& \text { (test sample, } \quad T D H 1 \text { and } f i b, \quad \text { copies } / \mathrm{ul} \text { ) } \\
& =\frac{\mathrm{OD}_{260} \times 50 \times \text { Dilution fold } \times 6.022 \times 10^{14}}{640 \times \text { Number of plasmid bases }}
\end{aligned}
$$

Table 2 Primers and probes used for plasmid construction and real-time quantitative PCR

\begin{tabular}{lll}
\hline & Sequence $\left(\mathbf{5}^{\prime} \rightarrow \mathbf{3}\right.$ ') & Annotation \\
\hline fib-F & GAATCGCAGGGAATCAAACGGG & PCR for pPIC9K-fib \\
fib-F & GCGGCCGTTAGTGGTATGATGGTGATGTTGAGCAGCAGCTTGAACGT & PCR for pPIC9K-fib \\
fib-R & GCAGGGAATCAAACGGG & PCR for pMD19T-fib \\
TDH1-F & TTGAGCAGCAGCTTGAACGT & PCR for pMD19T-fib \\
TDH1-R & ATGGCTATCACTGTCGGTATTAACG & PCR for pMD19T-TDH1 \\
qfib-F & TTAAGCCTTAGCAACGTGTTG & PCR for pMD19T-TDH1 \\
qfib-R & TTGCCGGTGGAGCTTCTATG & qPCR for fib \\
Probe-fib & CAACAGAGTTGTTCAAAGCAGCA & qPCR for fib \\
qTDH1-F & HEX-TCCATTCCAAGATTACAACTCTCATGG-BHQ-1 & qPCR for fib \\
qTDH1-R & CGGTGTTTCACCACTTTGGA & qPCR for TDH1 \\
Probe-TDH1 & CAACGAACATTGGAGCATCCT & qPCR for TDH1 \\
\hline
\end{tabular}




$$
\begin{aligned}
& \text { Copy number } \text { target gene, } f i b) \\
& =\frac{\text { Absolute copies }(\text { target gene, } f i b)_{\text {Absolute copies }(\text { reference gene, } T D H 1)}}{}
\end{aligned}
$$

\section{Fermentation optimization in flasks and 5-L fermenter}

In order to establish an efficient and low-cost process for recombinant fibase production, the medium (glucose-free YPD and BMMY), time-course (1-9 days), temperature $\left(28^{\circ} \mathrm{C}, 32^{\circ} \mathrm{C}\right.$, and $\left.36^{\circ} \mathrm{C}\right)$, methanol concentration for induction $(0.5,1$, and $2.5 \%)$, and coculture of methanol and sorbitol ( $0,2,4$, and $6 \mathrm{~g} / \mathrm{l})$ conditions were optimized via an extensive series of shake flask experiments. The shake flask study under optimized condition was performed in $50 \mathrm{ml}$ media in $250 \mathrm{ml}$ shaker flasks. Methanol was added every $24 \mathrm{~h}$ to different final concentration to maintain induction. The results of optimization were then verified in scaled up production in a 5 -L fermenter with 2.41 medium volume. The main parameters utilized during the entire fermentation process are shown in Table S1. All values are means \pm SD from three independent experiments.

\section{Determination of fibrinolytic activity and protein concentration}

Fibrinolytic activity was assayed via the standard fibrin plate method using urokinase [29], with some modifications. Each $10-\mathrm{ml}$ plate contained $0.1 \%$ fibrinogen, $1 \%$ agarose, and $10 \mathrm{U}$ thrombin. A total of $5 \mu \mathrm{l}$ of culture supernatant at various dilutions was added to each well. The plate was incubated for $18 \mathrm{~h}$ at $37^{\circ} \mathrm{C}$, and fibrinolytic activity was determined based on the standard curve of urokinase. One enzyme unit is defined as the enzyme amount producing a $\Delta \mathrm{A} 275$ of 1.0 per $\mathrm{ml}$ per minute at $37^{\circ} \mathrm{C}, \mathrm{pH} 7.5$, when measuring perchloric acid soluble products from $\alpha$-casein. All data are presented as the mean \pm SD of triplicate determinations. The concentration of recombinant fibase was measured using nucleic acid/protein analyzer.

\section{Purification and sodium dodecyl sulfate polyacrylamide gel electrophoresis (SDS-PAGE)}

Utilizing the $6 \mathrm{His}$ tag at the $\mathrm{C}$-terminal end the recombinant protein was concentrated using an ultrafilter tube and purified with nickel ion affinity chromatograph resin (Ni-NTA) to obtain a single band. The buffer systems utilized were Ni-50 wash buffer $(50 \mathrm{mM}$ imidazole, 300 $\mathrm{mM} \mathrm{NaCl}, 50 \mathrm{mM} \mathrm{NaH} \mathrm{PO}_{4}, \mathrm{pH} 8.0$ ), Ni-250 elution buffer (250 mM imidazole, $300 \mathrm{mM} \mathrm{NaCl}, 50 \mathrm{mM}$ $\mathrm{NaH}_{2} \mathrm{PO}_{4}, \quad$ pH 8.0), cleaning-in-place buffer $(0.5 \mathrm{M}$ $\mathrm{NaOH})$, stripping buffer $\left(50 \mathrm{mM} \mathrm{Na} \mathrm{PO}_{4} \cdot 12 \mathrm{H}_{2} \mathrm{O}, 300\right.$ $\mathrm{mM} \mathrm{NaCl}, 100 \mathrm{mM}$ EDTA $\cdot \mathrm{Na}_{2}$ ), and regeneration buffer $\left(100 \mathrm{mM} \mathrm{NiSO} \cdot 6 \mathrm{H}_{2} \mathrm{O}\right)$. All purification processes were conducted at $4{ }^{\circ} \mathrm{C}$. Purification recovery refers to the ratio of total activity before and after purification.

SDS-PAGE was conducted on a Mini-PROTEAN 3 cell apparatus (Bio-Rad, USA) using the tris-glycine discontinuous system with $5 \%$ stacking and $12 \%$ resolving gels. An unstained protein marker, ProteinRuler II (TRAN, 12-120 kDa) was used as molecular weight standards. Proteins were stained using the Coomassie Brilliant Blue R-250 method.

\section{Characteristics of recombinant protein}

Residual fibase activity under the different treatments was determined via the fibrin plate method. The determination of optimal temperature was performed by measuring fibase activity in $0.02 \mathrm{M}$ phosphate-buffered saline ( $\mathrm{pH} 7.4$ ) from $28^{\circ} \mathrm{C}$ to $60^{\circ} \mathrm{C}$. The thermal stability of fibase was determined after incubation in the same buffer and temperatures for $1 \mathrm{~h}$ or $6 \mathrm{~h}$.

To determine the optimum $\mathrm{pH}$, enzymatic activity measurements were performed at levels ranging from $\mathrm{pH} 4.0$ to $\mathrm{pH}$ 10.0. To investigate the $\mathrm{pH}$ stability of the purified enzyme, enzyme samples were diluted to the same concentration with $0.02 \mathrm{M}$ disodium hydrogen phosphate-sodium citrate ( $\mathrm{pH} 4.0-6.0$ ), $0.02 \mathrm{M}$ Tris- $\mathrm{HCl}$ (pH 7.0-8.0), and $0.02 \mathrm{M}$ glycine-sodium hydroxide $(\mathrm{pH}$ 9.0-10.0). Residual fibase activity was measured after incubation at $37^{\circ} \mathrm{C}$ for $18 \mathrm{~h}$.

Salt solutions containing different metal ions were prepared, and purified enzymes were added to 5, 20, and $50 \mathrm{mM}$ salt solutions. The residual fibase activity of each enzyme was determined via fibrin plates. Fibase activity with no salt was set as $100 \%$.

The kinetic parameters $\mathrm{K}_{\mathrm{m}}$ and $\mathrm{V}_{\max }$ for fibase were calculated using chromogenix as the substrate at concentrations of $0.0,0.1,0.3,0.6,0.9$, and $1.2 \mathrm{mM}$. The kinetic study was performed at $37^{\circ} \mathrm{C}$ and $\mathrm{pH} 7.4$ (phosphate buffer, $0.02 \mathrm{M}$ ). Fibase was incubated with substrates at different concentrations at $37^{\circ} \mathrm{C}$ for $8 \mathrm{~min}$, and absorption values at $405 \mathrm{~nm}$ were measured. The amount $(\mu \mathrm{M})$ of 4-nitroanilide released by the reaction between tetrapeptide substrate and protease per unit of time was considered to be the velocity of the reaction.

All values above are mean \pm SD from three independent experiments.

\section{Results}

\section{Expression of yeast codon optimized strains}

K. phaffii is a methylotrophic yeast without fibrinolytic activity, the expression efficiency of which is higher than that of Saccharomyces cerevisiae due to the tight regulation and strong inducibility of the AOX1 promoter when methanol is used as the sole carbon source [22]. The recombinant strain GS115 (pPIC9K-fib) was cultivated with a $2 \%$ inoculum size and daily addition of $1 \%(\mathrm{v} / \mathrm{v})$ 
methanol to a shaking flask containing $50 \mathrm{ml}$ BMMY at pH 6.0 and $30^{\circ} \mathrm{C}$.

A main protein band with a molecular weight of 46 $\mathrm{kDa}$ was detected via SDS-PAGE of positive culture supernatants with the highest fibase activity after supernatant concentration (Fig. 2c). No corresponding band was yielded by the transformant with pPIC9k, and the result was consistent with that of fibrin plates (Fig. 2b). Therefore, recombinant fibase was secreted into the supernatant by $K$. phaffii GS115. The $6 \mathrm{His}$ tag at the carbon end facilitated purification of the recombinant protein via nickel ion affinity chromatograph resin, and it was analyzed via SDS-PAGE (Fig. 2a).

\section{Quantification of fib copy number in K. phaffii genome}

The melt curves of both TDH1 and fib only had a single peak, indicating specificity of the qPCR products (Fig. S2A and S2B). The amplification efficiency of $T D H 1$ was $94.8 \%$, and that of $f i b$ was $96.3 \%$. The regression equation of the $T D H 1$ standard curve was $\mathrm{y}=-3.441 \mathrm{x}+34.952\left(\mathrm{R}^{2}=\right.$ $0.999)$, and that of $f i b$ was $y=-3.511 \mathrm{x}+37.563\left(\mathrm{R}^{2}=\right.$ 0.998) (Fig. 3). The fib copy numbers in the recombinant strain with the highest activity and the other four strains were 5.4, 6.0, 8.0, 8.7 and 12.3 (Table 3). The corresponding strain were named GS115/fib-5.4c, fib-6c, fib-8c, fib-9c, and fib-12c with fibrinolytic activity $4428 \mathrm{U} / \mathrm{ml}, 5781 \mathrm{U} / \mathrm{ml}$, $7323 \mathrm{U} / \mathrm{ml}, 7930 \mathrm{U} / \mathrm{ml}, 2472 \mathrm{U} / \mathrm{ml}$ respectively.

\section{Fermentation optimization in flasks and 5-L fermenter}

After optimization the maximum fibase activity was obtained with a $2 \%$ inoculum size, and the optimal culture conditions included daily addition of $0.5 \%(\mathrm{v} / \mathrm{v})$ methanol and $2 \mathrm{~g} / \mathrm{l}$ sorbitol to a $250 \mathrm{ml}$ shaking flask containing $50 \mathrm{ml}$ of glucose-free YPD (1\% yeast extract and $2 \%$ peptone) culture medium for $120 \mathrm{~h}$ at $\mathrm{pH} 6.0$ and $32{ }^{\circ} \mathrm{C}$ (Fig. 4). Based on the optimized conditions of fibase recombinant strain cultivation in shaking flasks, the fermentation process in the $5 \mathrm{~L}$-fermenter was established. The highest fibase expression level of the strain expressing fib-9c was $7930 \mathrm{U} / \mathrm{ml}$ in a shake flask and increased to $12,690 \mathrm{U} / \mathrm{ml}$ after 3 days of continuous culture in a 5L fermenter (Fig. 5).

\section{Characteristics of recombinant protein}

Effects of $\mathrm{pH}$ and temperature on fibase activity and stability.

As shown in Fig. 6, the purified fibase had high relative activity ( $>65 \%$ of maximum) at $\mathrm{pH}$ values ranging from 4.0 to 10.0 and the optimum $\mathrm{pH}$ was 8.0 . The purified fibase exhibited maximal activity at $45^{\circ} \mathrm{C}$, and it was stable and retained over $90 \%$ of its initial activity after incubation for $1 \mathrm{~h}$ at temperatures between $28^{\circ} \mathrm{C}$ and $50^{\circ} \mathrm{C}$. Even after incubation for $6 \mathrm{~h}$ at $50^{\circ} \mathrm{C}$ the residual relative activity was $>75 \%$.

\section{Effects of metal ions on fibase activity}

The effects of different metal ions on fibase activity as determined via fibrin plates after dilution to various different concentrations are shown in Table 4. With the exception of activation by $\mathrm{Ca}^{2+}$ and $\mathrm{Mg}^{2+}$, all other metal ions investigated inhibited fibase activity.

\section{Kinetic studies}

The kinetic parameters $K_{m}$ and $V_{\max }$ for fibase calculated using chromogenix substrate s-2251 as a substrate were $2.7 \mathrm{mmol} / \mathrm{l}$ and $0.03 \mathrm{mmol} / \mathrm{l}^{\prime} \mathrm{min}$ respectively (Fig. S3). The lower $K_{m}$ value of the purified fibase in the present

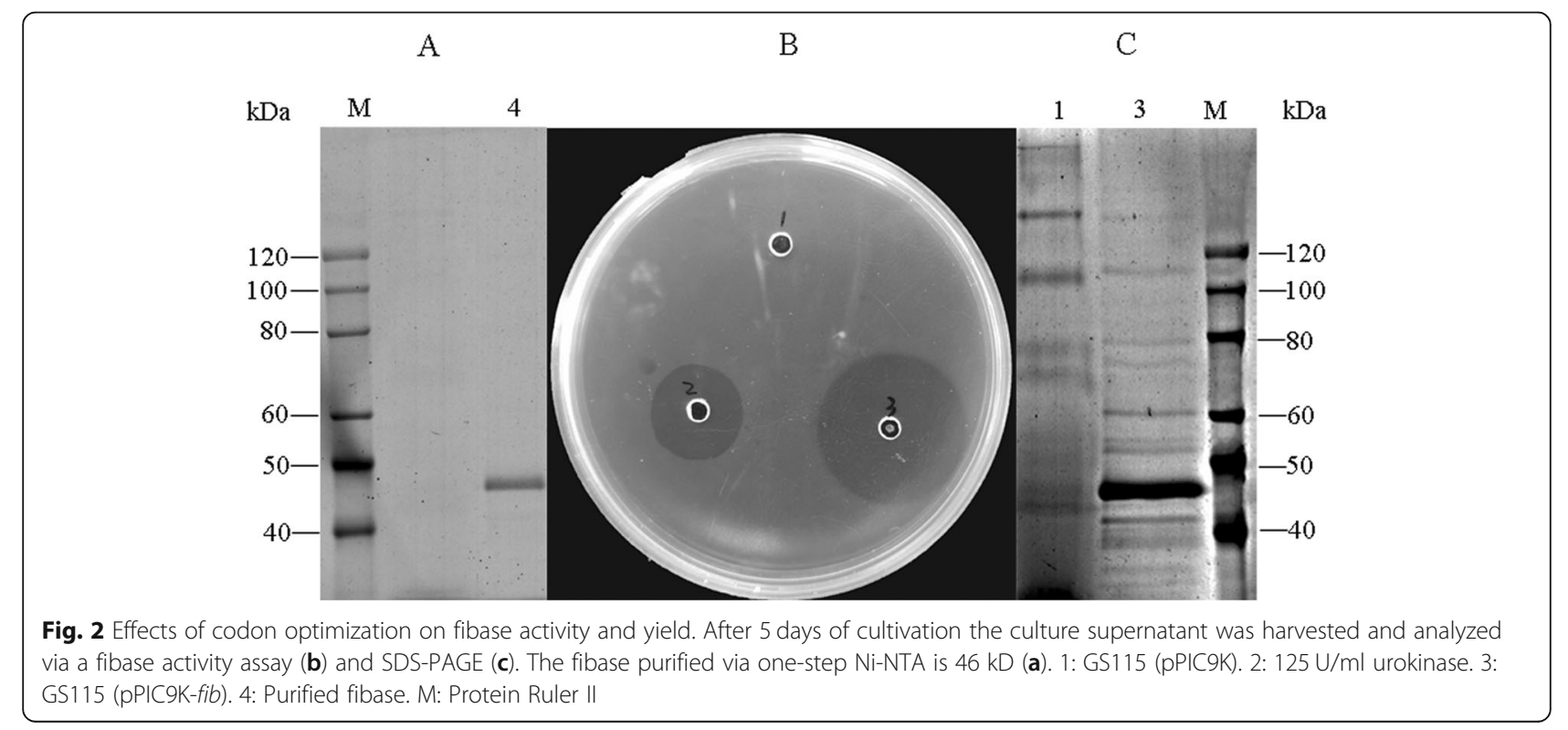



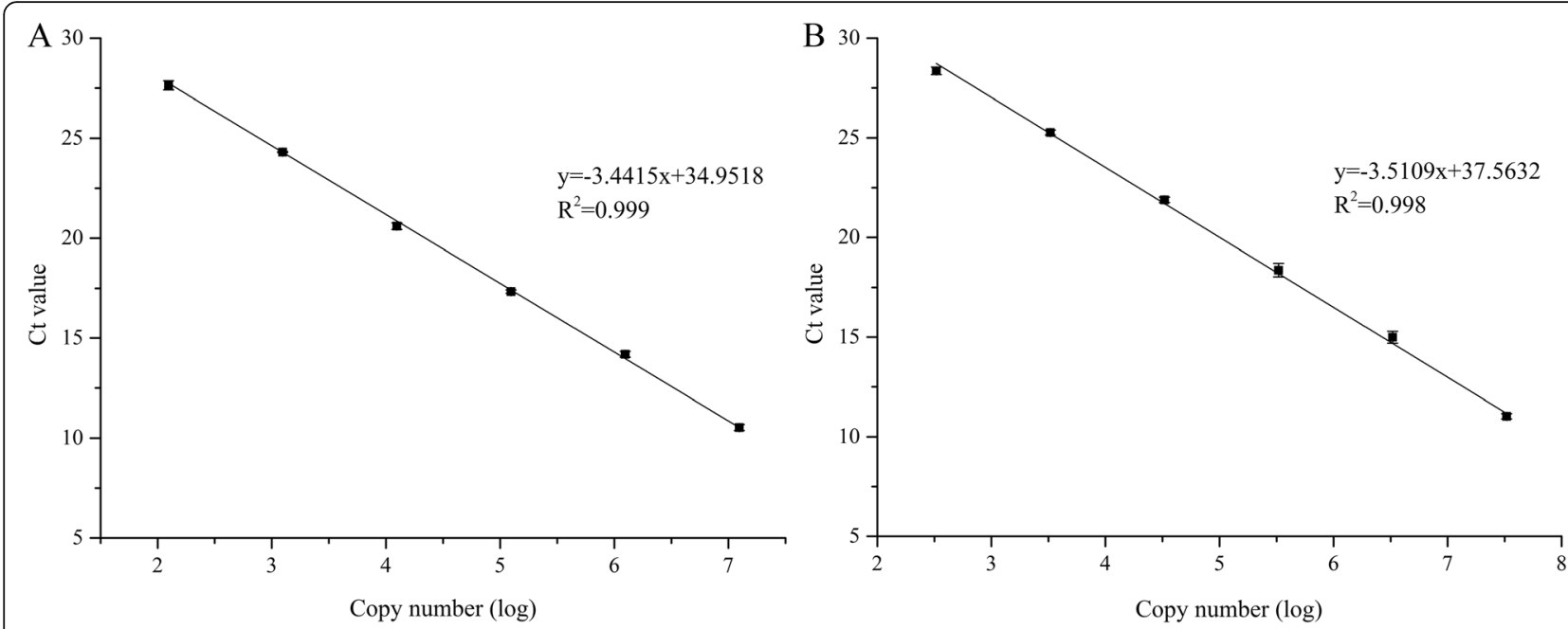

Fig. 3 Standard curves of the reference gene TDH1 (a) and the target gene fib (b). Data are mean \pm SD of three independent runs

study indicated that it had a greater affinity for the substrate.

\section{Mechanisms of fibrinolytic effects and in vitro hemolysis assays}

As shown in Fig. 7a and b the sizes of the translucent zones generated by purified enzyme on the two plates were very similar, but urokinase did not generate a translucent zone on the heated fibrin plate, suggesting that the mechanism of action of purified enzyme involves direct thrombolysis. Purified fibase did not form a translucent zone on the bovine blood agar plate, unlike the crude enzyme, indicating that the purified fibase did not induce hemolysis in vitro (Fig. 7c). Therefore, it may be a potential thrombolytic agent with low bleeding risk for safe therapy.

\section{Discussion}

Codon optimization is a key efficient strategy and measure to improve the expression, which has been repeatedly demonstrated to increase heterologous protein expression in $K$. phaffii. The expressions of a codonoptimized lip2 gene from spergillus niger was enhanced 11.6-fold compared to the native gene [30]. Codon optimization of the endoinulinase gene resulted in 4.8fold increases in enzyme activity [31]. Compared with the expression level of native hBMP4 sequence $(12 \mathrm{mg} /$ $\mathrm{L})$, there is a 4-fold increase in that from the optimized sequence $(48 \mathrm{mg} / \mathrm{L})$ [32]. There are several factors remarkably affecting the expression of foreign genes in $K$. phaffii, containing codon usage bias, GC content, transcriptional and translational blocks, and secondary structure of mRNA et al. The optimization of these factors could finally result in an increase of protein synthesis.

The fib gene used in the current study was originated from a marine $B$. subtilis isolated from a coastal mangrove area in Beihai City in Guangxi, China. Marine microorganisms can survive in the extreme ocean environment, wherein the $\mathrm{pH}$ is similar to that of the internal environment of the human body. Therefore, marine microbes are considered a rich source of bioactive compounds that have high medicinal value [33, 34].

Table 3 Fibrinolytic enzyme activity and TDH1 and fib gene copy numbers detected via real-time quantitative PCR

\begin{tabular}{|c|c|c|c|c|c|c|}
\hline \multirow[t]{2}{*}{ Strain } & \multirow{2}{*}{$\begin{array}{l}\text { Fibase } \\
\text { activity }\end{array}$} & \multicolumn{2}{|l|}{$\mathrm{Ct}$ value } & \multicolumn{2}{|c|}{ Gene copy $\left(10^{n}\right)$} & \multirow[b]{2}{*}{$\begin{array}{l}\text { Copy } \\
\text { numbers } \\
\text { of fib } \\
\text { gene } \\
\text { (fib/TDH1 } \\
\text { copy } \\
\text { number) }\end{array}$} \\
\hline & & fib gene & TDH1 gene & fib gene & TDH1 gene & \\
\hline GS115/ fib-5.4c & 4428 & $26.00 \pm 0.12$ & $26.22 \pm 0.59$ & $18.6 \pm 1.46$ & $3.45 \pm 1.20$ & 5.4 \\
\hline GS115/ fib-6c & 5781 & $16.13 \pm 0.02$ & $16.99 \pm 0.23$ & $14.9 \pm 1.88$ & $2.50 \pm 0.42$ & 6.0 \\
\hline GS115/ fib-8c & 7323 & $16.00 \pm 0.19$ & $16.40 \pm 0.24$ & $13.4 \pm 0.14$ & $1.68 \pm 0.27$ & 8.0 \\
\hline GS115/ fib-9c & 7930 & $16.23 \pm 0.04$ & $17.19 \pm 0.07$ & $12.6 \pm 0.32$ & $1.45 \pm 0.07$ & 8.7 \\
\hline GS115/ fib-12c & 2472 & $26.35 \pm 0.19$ & $27.71 \pm 0.19$ & $14.8 \pm 1.88$ & $1.21 \pm 0.15$ & 12.3 \\
\hline
\end{tabular}

Data are presented as the mean \pm SD of triplicate determinations 

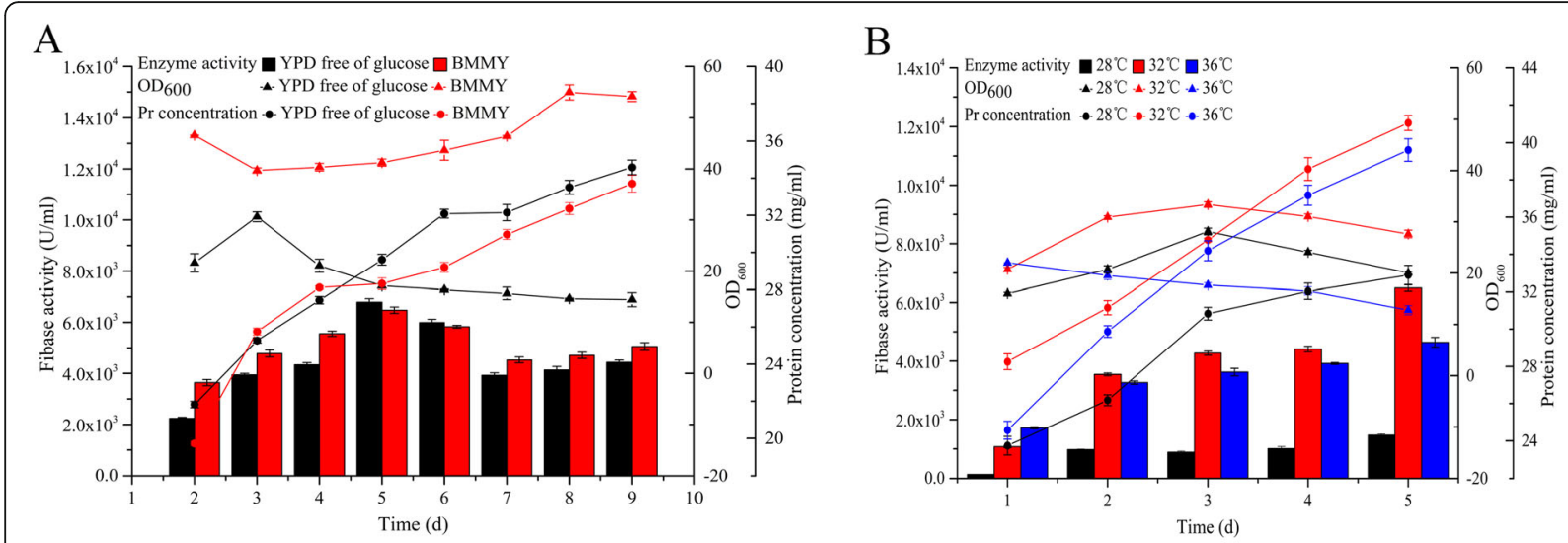

C
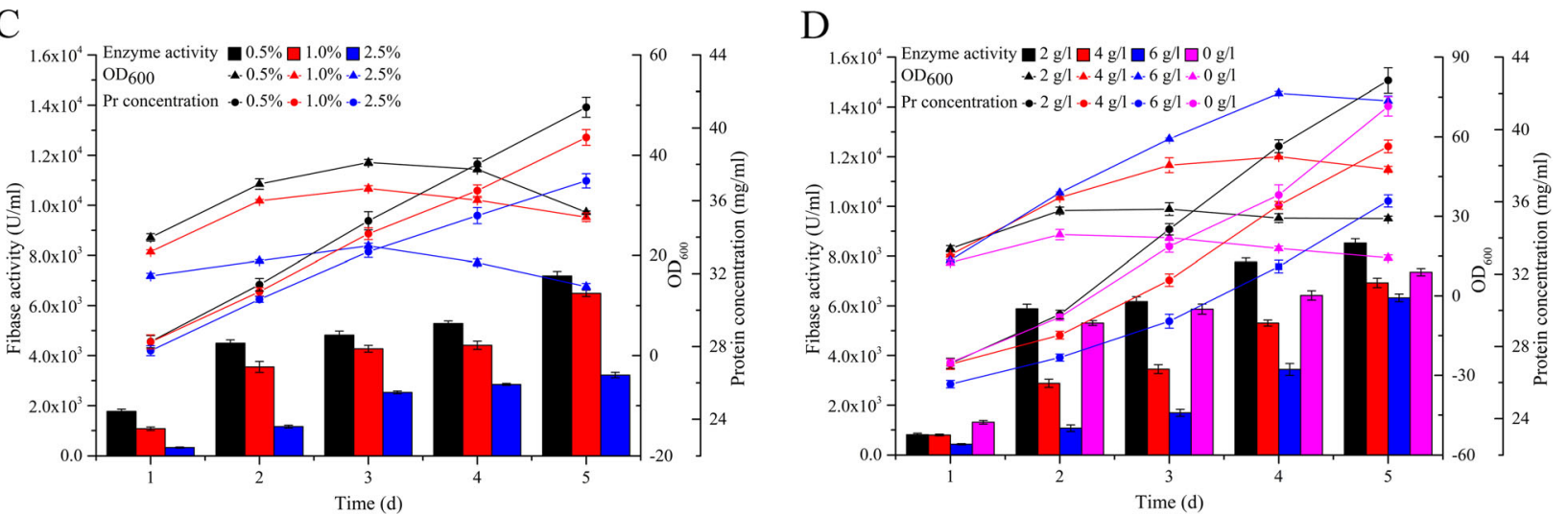

Fig. 4 Cultivation optimization of recombinant strain GS115/pPIC9K-fib in shaking flasks. The figures show the effect of different media and days (a), induction temperatures (b), methanol concentrations (c), coculture with methanol and sorbitol (d) on enzyme activity (column), growth (line and triangle), and protein concentration (line and circular), respectively. All values are mean \pm SD from three independent experiments

Since the 1960s thousands of novel secondary metabolites with antitumor, antiviral, antibacterial, antifungal, and anticoagulant activities have been isolated from marine microorganisms [35]. The recombinant fibase remained active over a broad $\mathrm{pH}(6.0-10.0)$ with optimum $\mathrm{pH} 8.0$, which is very close to the physiological $\mathrm{pH}$. Its optimum $\mathrm{pH}$ is quite different from many other fibrinolytic enzymes, but similar to fibrinolytic enzymes
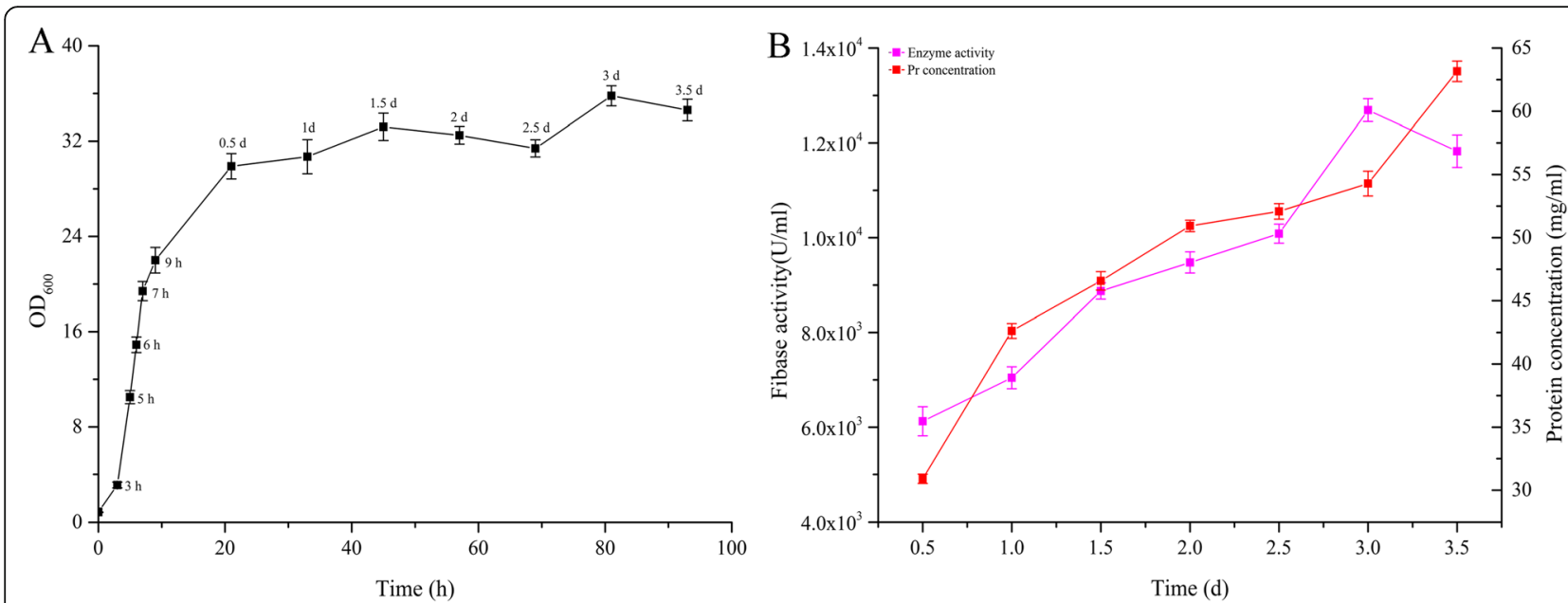

Fig. 5 The growth, enzyme activity, and protein concentration from fermentations of recombinant strain GS115/pPIC9K-fib in 5-L fermenter. Data are presented as mean \pm SD of triplicate experiments 


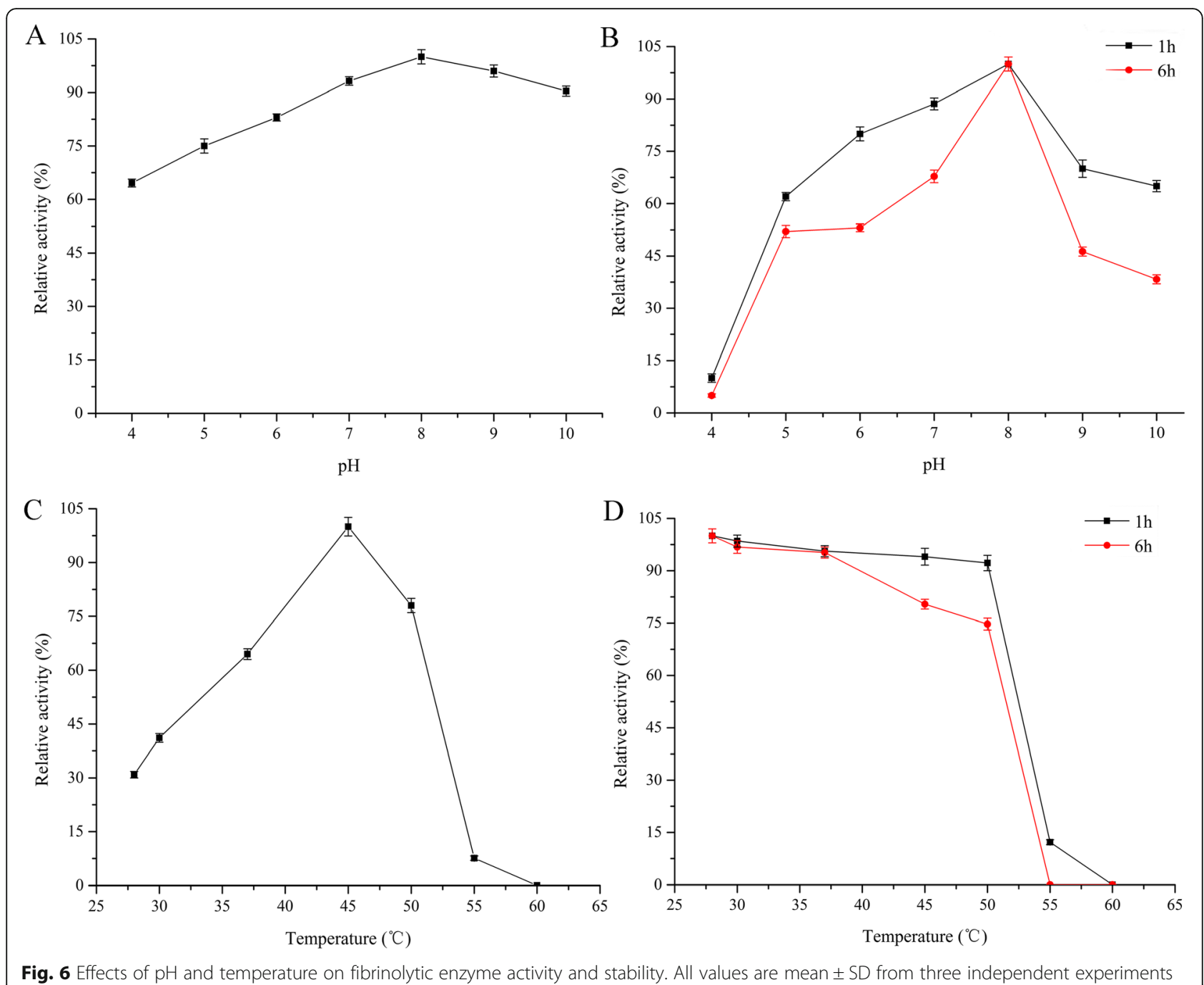

Table 4 Effects of metal ions on fibrinolytic enzyme activity

\begin{tabular}{llll}
\hline $\begin{array}{l}\text { Metal } \\
\text { ions }\end{array}$ & \multicolumn{3}{l}{ Concentration relative activity (\%) } \\
\cline { 2 - 4 } $\mathbf{5} \mathbf{~} \mathbf{M}$ & $\mathbf{2 0} \mathbf{~} \mathbf{M}$ & $\mathbf{5 0} \mathbf{~ m M}$ \\
\hline $\mathrm{Ca}^{2+}$ & $117.5 \pm 1.8$ & $121.2 \pm 2$ & $97.1 \pm 1.2$ \\
$\mathrm{Mg}^{2+}$ & $100.5 \pm 1$ & $108.9 \pm 1.4$ & $98.0 \pm 2.1$ \\
$\mathrm{Zn}^{2+}$ & $8.1 \pm 1.4$ & $4.5 \pm 1.2$ & $1.8 \pm 1.0$ \\
$\mathrm{Cu}^{2+}$ & $5.4 \pm 1.9$ & $0.0 \pm 1.0$ & 0 \\
$\mathrm{Mn}^{2+}$ & $88.3 \pm 1.6$ & $7.3 \pm 1.4$ & 0 \\
$\mathrm{~Pb}^{2+}$ & 0 & 0 & 0 \\
$\mathrm{Fe}^{3+}$ & 0 & 0 & 0 \\
$\mathrm{CK}^{\mathrm{b}}$ & 100 & 100 & 100 \\
\hline
\end{tabular}

${ }^{a}$ The relative activity with different metal ions added was determined and compared with the activity measured in phosphate buffer ( $\mathrm{pH} 7.4,0.02 \mathrm{M})$ without the addition of any ions

${ }^{\mathrm{b}}$ The relative activity measured in phosphate buffer $(\mathrm{pH} 7.4,0.02 \mathrm{M})$ without the addition of any ions

All values are mean $\pm S D$ from three independent experiments derived from high-salt environments, such as seas [36] and douchi [37]. Additionally, the purified fibase had high tolerance to the increasing temperature. As a metal-dependent serine protease, fibase did not cause hemolysis in vitro and preferentially degraded fibrin directly. All these characteristics exhibited its desirable adaptation to the internal environment of human body and great potential for application in thrombosis prevention and/or therapy.

An additional yield-limiting factor of recombinant protein is the efficiency of purification and recovery. Conventionally, separation and purification of wild fibase relies on methods like phenylene anion exchange, gel filtration, and hydrophobic interaction chromatography et al., which are complex operations resulting in low yields. Here, the fibase was purified by one-step NiNTA, achieving a $27 \pm 2 \%$ recovery. The recovery was much higher than those of other fibrinolytic enzymes ever reported, such as $7.5 \%$ recovery from $B$. subtilis 


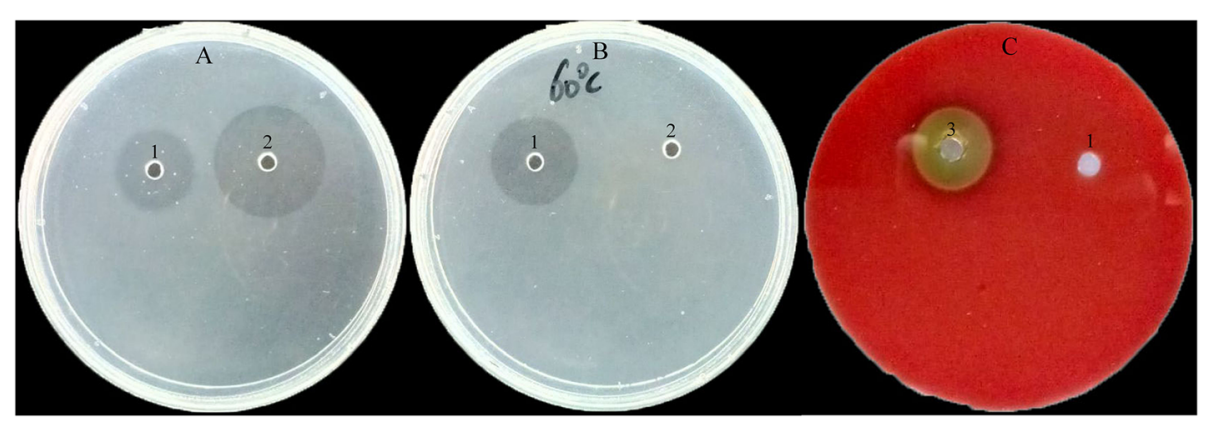

Fig. 7 Mechanisms of fibrinolytic effects (a, b), and the hemolysis assay in vitro (c). In contrast to the urokinase (2), the purified enzyme (1) generated translucent zones of equal size on fibrin plates containing both plasminogen and fibrinogen (a) and fibrinogen only (b). The purified enzyme did not generate a translucent zone on a blood agar thus it did not induce hemolysis in vitro, unlike the crude extract (3)

ICTF-1 [38], 6.46\% recovery from Chive (Allium tuberosum) [6], and 7.82\% recovery from Pseudomonas baetica SUHU25. This method is highly efficient and suited for large-scale purification of target protein.

Heterologous gene copy number reportedly plays an important role in the yield of recombinant proteins in $K$. phaffii expression systems [39]. In recent studies the activity of recombinant protein increased as the copy number increased from 4 to 9 , but it decreased dramatically when the copy number continued to increase. That is a result of the negative effects of a high concentration of target protein on the growth and metabolism of the strain [40-42]. Song et al. (2019) reported that a co-expressing strain (pro/rDNA- $m t g$ ) with three copies of $m t g$ genes $(m t g-3 \mathrm{c}$ ) exhibited higher transglutaminase activity than $m t g-2 c$, $m t g-6 c$, or $m t g-8 c$ [25]. Dagar et al. (2018) reported that the expression of human interleukin-3 protein increased with the addition of up to 8 copies of the expression cassettes, then drastically decreased thereafter [26]. Fang et al. (2014) reported that the respective maximum lipase activities of three recombinant strains with copy numbers of 7, 5, and 3 were $6600 \mathrm{U} / \mathrm{ml}, 6000 \mathrm{U} / \mathrm{ml}$, and $4800 \mathrm{U} / \mathrm{ml}$ [27]. Therefore, the optimal copy number for high expression by $K$. phaffii needs to be evaluated via screening experiments, and it is not simply a case of "the more copies the better" [42]. After the optimal gene copy number has been evaluated, the main limitations of heterologous protein secretory expression pertain to protein translation, post-translational modification, and targeted delivery of protein precursors, which may be the main bottlenecks affecting yields $[43,44]$.

In order to provide a reference for the large-scale industrial production, the fermentation scale needs to be verified. There are many factors that affect fibrinolytic activity; thus the fermentation process needs prior optimization, which were initially performed at shake flask level to reduce cost and improve efficiency followed by fermenter study. As a complex and nutrient-rich medium, YPD free of glucose is prone to foaming.
However, excessive antifoam may be toxic to cell growth, and to avoid this problem, an increase in inoculum size $(10 \%)$ is required to allow cells to enter the log phase after $3 \mathrm{~h}$. The rapid proliferation of $K$. phaffii resulted in faster consumption of available nutrients, and the decrease of medium foaming ability. Notably, $K$. phaffii showed transient secondary growth at 3 days, the reason of which may be that at least one nutrient had been used up and other nutrients started to be consumed. In addition, the initial induction biomass has been reported an important impact on recombinant protein yields [45]. If the cell density is too high, cell growth and metabolism will be restricted, resulting in a low enzyme activity; while if the cell density is too low, the induction phase will be much longer. The fibase activity of the strain expressing fib-9c was $12,690 \mathrm{U} / \mathrm{ml}$ after 3 days in a 5 -L fermenter, which was 1.6-fold the highest fibase activity in shake flasks. The clear difference in fibase yield might attribute to the great difference between the fermentation conditions of fermenter and shaking flasks.

With the development of microbial technology, efficient protein expression could be achieved via genetic or engineering technologies. Some recently reported studies have investigated the homologous and heterologous expression of fibase, but their expression levels are typically low (Table 5). A study by Lv et al. overexpressed the recombinant plasmid pET-DsbA/PPFE-I in E. coli BL21 (DE3) and achieved maximum fibase activity of $228 \mathrm{U} /$ $\mathrm{mL}$ after IPTG induction at $30^{\circ} \mathrm{C}$ for $1.5 \mathrm{~h}$, a level almost 2 times higher than that of wild strain $P$. polymyxa EJS-3 [8]. Fib gene (subtilisin DFE) fused with $\alpha$-amylase promoter and signal peptide was successfully expressed in B. subtilis WB600, achieving a fibrinolytic activity of $200 \mathrm{U} / \mathrm{mL}$. And it was 4-fold higher than that under the control of subtilisin DFE promoter [46]. Yao et al. transformed the fibase recombinant plasmid pHY300PLK/ aprEBS15 into B. subtilis WB600 and achieved recombinant protein maximum fibrinolytic activity of $408.2 \mathrm{U} /$ $\mathrm{ml}$ after induction at $37^{\circ} \mathrm{C}$ for $96 \mathrm{~h}$ [47]. Several possible 
Table 5 Summary of recent reports of fibrinolytic enzyme expression in the literature

\begin{tabular}{|c|c|c|c|}
\hline Wild-type strain & Host (strains/plasmids) & Fibase activity & References \\
\hline Paenibacillus polymyxa EJS-3 & E. coli BL21 (DE3)/pET-DsbA & $228.0 \mathrm{U} / \mathrm{ml}$ & [8] (Lv et al. 2015) \\
\hline Bacillus amyloliquefaciens & B. subtilis WB600/pSUGV4 & $200.0 \mathrm{U} / \mathrm{ml}$ & [46] (Xiao et al. 2004) \\
\hline Bacillus pumilus BS15 & B. subtilis WB600 /pHY300PLK & $408.2 \mathrm{U} / \mathrm{ml}$ & [47] (Yao et al. 2018) \\
\hline Bacillus pumilus BS15 & none & $242.5 \mathrm{U} / \mathrm{ml}$ & [47] (Yao et al. 2018) \\
\hline Xanthomonas oryzae IND3 & none & $2294 \pm 12.8 \mathrm{U} / \mathrm{g}$ & [48] (Vijayaraghavan et al. 2019) \\
\hline Serratia KG-2-1 & none & $250.4 \mathrm{U} / \mathrm{ml}$ & [9] (Taneja et al. 2017) \\
\hline Serratia rubidaea & none & $394.9 \mathrm{U} / \mathrm{ml}$ & [49] (Anusree et al. 2020) \\
\hline Bacillus sp. IND12 & none & $4143 \mathrm{U} / \mathrm{g}$ & [50] (Vijayaraghavan et al. 2017) \\
\hline Cordyceps militaris & none & $120.0 \mathrm{U} / \mathrm{ml}$ & [51] (Liu et al. 2017) \\
\hline B. subtilis D21 & none & $279 \mathrm{U} / \mathrm{ml}$ & This research \\
\hline B. subtilis D21 & K. phaffii GS115/pPIC9K & $7930 / 12690 \mathrm{U} / \mathrm{ml}$ & This research \\
\hline
\end{tabular}

reasons might account for such a low production. First, the yield of recombinant fibase depends greatly on vector-host system. More specifically, high expression is generally associated with high-copy plasmids, and suitable host with high promoter activity plus high secretion efficiency. Second, the recombinant fibase might misfold into non-functional conformation, leading to aggregation or proteolytic digestion of misfolded protein. Third, the recombinant fibase may be toxic to the hosts, causing the host's slow growth, impaired metabolism, or even death during expression. In order to improve the production of fibase in a high-efficiency $K$. phaffii expression system in the present study, various genetic and process engineering cultivation strategies were utilized at different levels. This resulted in improved fibase activity levels of up to $7930 \mathrm{U} / \mathrm{ml}$ in shake flasks and 12,960 U/ $\mathrm{ml}$ in 5-L fermenter, which is among the highest levels of fibase production ever reported.

\section{Conclusions}

To conclude, in this work, the optimized fib gene was expressed at different copy numbers in $K$. phaffii to study the association between fibase production and gene dosage. Relative gene copy numbers were assessed by qPCR. The results showed that, the fibase levels increased as the copy number increased from 4 to 9 , but decreased dramatically at copy number 12 . The fermentation optimization of the strain expressing fib-9c was initially done at shake flask.

level and then fermenter verification, with the maximum fibase activity 7930 and 12,690 U/ml, respectively. The strategies developed in this work could be used to improve the expression of other therapeutic proteins that are difficult to express. The superior enzymatic properies of the purified fibase suggest that it has potential applications for the therapy and/or prevention of thrombosis.

\section{Supplementary Information}

The online version contains supplementary material available at https://doi. org/10.1186/s12896-020-00654-7.

Additional file 1: Fig. S1. Sequence of optimized and original fib gene. Upper row: the optimized fib sequence, lower row: the original fib sequence, different nucleic acids are marked with red.

Additional file 2: Fig. S2. Detection of fib copy number in the K. phaffii genome via a double standard curve method. (A) and (B) are the melting curves of TDH1 and fib genes, and (C) and (D) are the amplification curves of TDH1 and fib genes.

Additional file 3: Fig. S3. Lineweaver-Burk plots for purified fibrinolytic enzyme using chromogenix as a substrate. The experiment was repeated three times independently.

Additional file 4: Table S1. Important parameters during the entire fermentation process.

\section{Abbreviations \\ Fibase: Fibrinolytic enzyme}

Acknowledgements

Not applicable.

Authors' contributions

$\mathrm{ZL}$ and $\mathrm{ZC}$ contributed in the conception and design of the research; ZC carried out the experiments and wrote the manuscript; XC and GC contributed to analysis, or interpretation of data; ZL revised the paper. All authors read and approved the final manuscript.

\section{Funding}

This work was supported by the National Natural Science Foundation of China $(31560448,21062001)$ and the Natural Science Foundation of Guangxi (2016GXNSFAA380130).

\section{Availability of data and materials}

All the data presented in the article are available from the corresponding author upon reasonable request.

Ethics approval and consent to participate Not applicable.

Consent for publication

Not applicable.

Competing interests

The authors declare that they have no competing interests 


\section{Author details}

'State Key Laboratory for Conservation and Utilization of Subtropical Agro-bioresources, Guangxi Microorganism and Enyme Research Center of Engineering Technology, College of Life Science and Technology, Guangxi University, Nanning 530004, China. ${ }^{2}$ College of Agriculture and Forestry Science, Linyi University, Linyi 276000, China.

\section{Received: 6 August 2020 Accepted: 5 November 2020}

\section{Published online: 04 December 2020}

\section{References}

1. Choi JH, Sapkota K, Park SE, Kim S, Kim SJ. Thrombolytic, anticoagulant and antiplatelet activities of codiase, a bi-functional fibrinolytic enzyme from Codium fragile. Biochimie. 2013;95:1266-77.

2. Blann AD, Landray MJ, Lip GYH. An overview of antithrombotic therapy. Brit Med J. 2002;325:762-5.

3. Wisner A. A novel plasminogen activator from Snake venom. J Biol Chem. 1995:270:10246-55.

4. Wu JX, Zhao XY, Pan R, He RQ. Glycosylated trypsin-like proteases from earthworm Eisenia fetida. Int J Biol Macromol. 2007:40:399-406.

5. lannucci NB, Camperi SA, Cascone O. Purification of lumbrokinase from Eisenia fetida using aqueous two-phase systems and anion-exchange chromatography. Sep Purif Technol. 2008;64:131-4.

6. Chung DM, Choi NS, Maeng PJ, Chun HK, Kim SH. Purification and characterization of a novel fibrinolytic enzyme from chive (Allium tuberosum). Food Sci Biotechnol. 2010;19:697-702.

7. Katrolia P, Liu X, Zhao Y, Kopparapu NK. Zheng. Gene cloning, expression and homology modeling of first fibrinolytic enzyme from mushroom (Cordyceps militaris). Int J Biol Macromol. 2019;146:897-906.

8. Lv FX, Zhang C, Guo FF, Lu YJ, Bie XM, Qian H, Lu ZX. Expression, purification, and characterization of a recombined fibrinolytic enzyme from endophytic Paenibacillus polymyxa EJS-3 in Escherichia coli. Food Sci Biotechnol. 2015:24:125-31.

9. Taneja K, Bajaj BK, Kumar S, Dilbaghi N. Production, purification and characterization of fibrinolytic enzyme from Serratia sp. KG-2-1 using optimized media. 3 Biotech. 2017;7:1-15

10. Wong SL. Advances in the use of Bacillus subtilis for the expression and secretion of heterologous proteins. Cur Opin Biotech. 1995;6:517-22.

11. Lam KHE, Chow KC, Wong WKR. Construction of an efficient Bacillus subtilis system for extracellular production of heterologous proteins. J Biotechnol. 1998:63:167-77.

12. Westers L, Dijkstra DS, Westers H, van Dij JM, Quax WJ. Secretion of functional human interleukin-3 from Bacillus subtilis. J Biotechnol. 2006;123:211-24.

13. Kodama T, Manabe K, Kageyama Y, Liu S, Ara K, Ozaki K, Sekiguchi J. Approaches for improving protein production in multiple protease-deficient Bacillus subtilis host strains. Adv Appl Microbiol. 2012;8:163-76.

14. Celik E, Calik P. Production of recombinant proteins by yeast cells. Biotechnol Adv. 2012;30:1108-18.

15. Idiris A, Tohda H, Kumagai H, Takegawa K. Engineering of protein secretion in yeast: strategies and impact on protein production. Appl Microbiol Blot. 2010;86:403-17.

16. Liu YK, Huang $\mathrm{H}$. Expression of single-domain antibody in different systems. Appl Microbiol Biot. 2018;102:539-51.

17. Eissazadeh S, Moeini H, Dezfouli MG, Heidary S, Nelofer R, Abdullah MP. Production of recombinant human epidermal growth factor in Pichia pastoris. Braz J Microbiol. 2017:48:286-93.

18. Barathiraja S, Gangadhara PAV, Umapathi V, Dechamma HJ, Reddy GR. Expression and purification of biologically active bovine interferon lambda3 (IL28B) in Pichia pastoris. Protein Express Purif. 2018;145:14-8.

19. Yu KM, Lau JYN, Fok M, Yeung YK, Fok SP, Shek F, Wong WT, Choo QL. Efficient expression and isolation of recombinant human interleukin-11 (rhIL-11) in Pichia pastoris. Protein Express Purif. 2018;146:69-77.

20. Polez S, Origi D, Zahariev S, Guarnaccia C, Tisminetzky SG, Skoko N, Baralle M. A simplified and efficient process for insulin production in Pichia pastoris. PLoS One. 2016:11:1-15.

21. Vandana Kantipudi S, Maheshwari N, Sharma S, Sahni G. Cloning and purification of an anti-thrombotic, chimeric Staphylokinase in Pichia pastoris. Protein Expres Purif. 2019;162:1-8.

22. Yang Z, Zhang Z. Engineering strategies for enhanced production of protein and bio-products in Pichia pastoris: a review. Biotechnol Adv. 2018:36:182-95.
23. Daly R, Hearn MT. Expression of heterologous proteins in Pichia pastoris: a useful experimental tool in protein engineering and production. J Mol Recognit. 2005;18:119-38.

24. Macauley-Patrick S, Fazenda ML, McNeil B, Harvey LM. Heterologous protein production using the Pichia pastoris expression system. Yeast. 2005;22:249-70.

25. Song XP, Shao CS, Guo YG, Wang YJ, Cai JJ. Improved the expression level of active transglutaminase by directional increasing copy of $\mathrm{mtg}$ gene in Pichia pastoris. BMC Biotechnol. 2019;19:1-9.

26. Dagar VK, Khasa YP. Combined effect of gene dosage and process optimization strategies on high-level production of recombinant human interleukin-3 (hlL-3) in Pichia pastoris fed-batch culture. Int J Biol Macromol. 2018;108:999-1009.

27. Fang ZG, Xu L, Pan DJ, Jiao LC, Liu ZY, Yan YJ. Enhanced production of Thermomyces lanuginosus lipase in Pichia pastoris via genetic and fermentation strategies. J Ind Microbiol Blot. 2014:41:1541-51.

28. Waterham HR, Digan ME, Koutz PJ, Lair SV, Cregg JM. Isolation of the Pichia pastoris glyceraldehyde-3-phosphate dehydrogenase gene and regulation and use of its promoter. Gene. 1997;186:37-44.

29. Astrup T, Müllertz S. The fibrin plate method for estimating Fibrinolytic activity. Arch Biochem Biophys. 1952;40:346-51.

30. Yang J, Liu LY. Codon optimization through a two-step gene synthesis leads to a high-level expression of Aspergillus Niger lip2 gene in Pichia pastoris. J Mol Catal B Enzym. 2010;63:164-9.

31. He M, Wu D, Wu J, Chen J. Enhanced expression of endoinulinase from Aspergillus niger by codon optimization in Pichia pastoris and its application in inulooligosaccharide production. J Ind Microbiol Biot. 2014;41:105-14.

32. Huang $Y$, Zhen BQ, Lin Y, Cai YH, Lin Z, Deng CM, Zhang YD. Expression of codon optimized human bone morphogenetic protein 4 in Pichia pastoris. Biotechnol Appl Bioc. 2014;61:175-83.

33. Ngo DH, Vo TS, Ngo DN, Wijesekara I, Kim SK. Biological activities and potential health benefits of bioactive peptides derived from marine organisms. Int J Bilo Macromol. 2012;51:378-83.

34. Romano G, Costantini M, Sansone C, Lauritano C, Ruocco N, lanora A. Marine microorganisms as a promising and sustainable source of bioactive molecules. Mar Environ Res. 2017;128:58-69.

35. Carroll AR, Copp BR, Davis RA, Keyzers RA, Prinsep MR. Marine natural products. Nat Prod Rep. 2019;36:122-73.

36. Vijayaraghavan P, Prakash Vincent SG. A low cost fermentation medium for potential fibrinolytic enzyme production by a newly isolated marine bacterium, Shewanella sp. IND20. Biotechnol Rep. 2015;7:135-42.

37. Hu YL, Yu D, Wang ZT, Hou JJ, Tyagi R, Liang YX, Hu YM. Purification and characterization of a novel, highly potent fibrinolytic enzyme from Bacillus subtilis DC27 screened from Douchi, a traditional Chinese fermented soybean food. Sci Rep-UK. 2019;9:1-10.

38. Mahajan PM, Nayak S, Lele SS. Fibrinolytic enzyme from newly isolated marine bacterium Bacillus subtilis ICTF-1: media optimization, purification and characterization. J Biosci Bioeng. 2012:113:307-14.

39. Zhu T, Guo M, Tang Z, Zhang M, Zhuang Y, Chu J, Zhang S. Efficient generation of multi-copy strains for optimizing secretory expression of porcine insulin precursor in yeast Pichia pastoris. J Appl Microbiol. 2009;107:954-63.

40. Marx H, Mecklenbrauker A, Gasser B, Sauer M, Mattanovich D. Directed gene copy number amplification in Pichia pastoris by vector integration into the ribosomal DNA locus. FEMS Yeast Res. 2009:9:1260-70.

41. Javitt G, Ben-Barak-Zelas Z, Jerabek-Willemsen M, Fishman A. Constitutive expression of active microbial transglutaminase in Escherichia coli and comparative characterization to a known variant. BMC Biotechnol. 2017;17:1-10.

42. Juturu V, Wu JC. Heterologous protein expression in Pichia pastoris. Latest Research Progress and Applications Chembiochem. 2018;19:7-21.

43. Li F, Yu XW, Sha C, Xu Y. Impact of gene dosage and methanol concentration on Rhizopus chinensis recombinant lipase production in Pichia pastoris. Microbiology China. 2011;38:301-9.

44. Li A, llie A, Sun Z, Lonsdale $\mathrm{R}, \mathrm{Xu}$ JH, Reetz MT. Whole-cell-catalyzed multiple Regio- and Stereoselective Functionalizations in Cascade reactions enabled by directed evolution. Angew Chem. 2016:55:12026-9.

45. Liu WC, Gong T, Wang QH, Liang X, Chen JJ, Zhu P. Scaling-up fermentation of Pichia pastoris to demonstration-scale using new methanol-feeding strategy and increased air pressure instead of pure oxygen supplement. Sci Rep-UK. 2016;6:1-12

46. Xiao L, Zhang RH, Peng $Y$, Zhang $Y Z$. Highly efficient gene expression of a fibrinolytic enzyme (subtilisin DFE) in Bacillus subtilis mediated by the promoter of a-amylase gene from Bacillus amyloliquefaciens. Biotechnol Lett. 2004:26:1365-9. 
47. Yao Z, Kim JA, Kim JH. Gene cloning, expression, and properties of a Fibrinolytic enzyme secreted by Bacillus pumilus BS15 isolated from Gul (oyster) Jeotgal. Biotechnol Bioproc E. 2018;23:293-301.

48. Vijayaraghavan P, Arasu MV, Anantha Rajan R, Al-Dhabi NA. Enhanced production of fibrinolytic enzyme by a new Xanthomonas onyzae IND3 using low-cost culture medium by response surface methodology. Saudi J Biol Sci. 2019;26:217-24.

49. Anusree M, Swapna K, Aguilar CN, Sabu A. Optimization of process parameters for the enhanced production of fibrinolytic enzyme by a newly isolated marine bacterium. Bioresour Technol Rep. 2020;11:1-7.

50. Vijayaraghavan P, Rajendran P, Vincent SGP, Arun A, Al-Dhabi NA, Arasu MV Kwon OY, Kim YO. Novel Sequential Screening and Enhanced Production of Fibrinolytic Enzyme by Bacillus sp IND12 Using Response Surface Methodology in Solid-State Fermentation. Biomed Res Int. 2017;2017:1-13.

51. Liu X, Kopparapu NK, Li Y, Deng Y, Zheng X. Biochemical characterization of a novel fibrinolytic enzyme from Cordyceps militaris. Int J Biol Macromol. 2017;94(Pt B):793-801.

\section{Publisher's Note}

Springer Nature remains neutral with regard to jurisdictional claims in published maps and institutional affiliations.

Ready to submit your research? Choose BMC and benefit from:

- fast, convenient online submission

- thorough peer review by experienced researchers in your field

- rapid publication on acceptance

- support for research data, including large and complex data types

- gold Open Access which fosters wider collaboration and increased citations

- maximum visibility for your research: over $100 \mathrm{M}$ website views per year

At $\mathrm{BMC}$, research is always in progress.

Learn more biomedcentral.com/submissions 